\title{
AMMONIA CONCENTRATION IN COW BARN UNDER LIMITED AIR EXCHANGE
}

\author{
Valerii Vtoryi, Sergei Vtoryi, Roman Ylyin \\ Federal Scientific Agroengineering Centre VIM, Russia \\ vvtoryj@yandex.ru
}

\begin{abstract}
Ammonia is significantly lighter than air and has high water solubility. In terms of the health effect, ammonia belongs to choking and neurotropic agents; under certain concentrations it can cause the pulmonary edema and severe damage to the nervous system of the workers and animals. This establishes the need to monitor the ammonia content in the cow barn air, especially in winter, when additional insulating measures are taken in the cow barns due to the negative outdoor temperatures and when the air exchange with the external environment is sharply reduced. The study was conducted in Leningrad Region of Russia in the operating typical cow barn with the dimensions of $21 \times 72 \mathrm{~m}$ for 200 lactating cows with the tied housing system and natural ventilation. The study was based on the instrumental express method using experiment designing, computer registration and data processing. The ammonia concentration and other inside climate parameters at certain points of the barn in a given time interval were measured. The ammonia concentration was found to depend on the air temperature and humidity in the barn, as well as on the external weather conditions, which affected these factors. During the observation period, the outside air temperature ranged from $-6.0^{\circ} \mathrm{C}$ to $-10.6{ }^{\circ} \mathrm{C}$, with the relative humidity being $72-84 \%$ and the absolute air humidity being $1.6-2.3 \mathrm{~kg}^{-3} \cdot \mathrm{m}^{-3}$. At the measurement points inside the barn, the air temperature ranged from 3.2 to $10.4{ }^{\circ} \mathrm{C}$, with the relative humidity being $72-90 \%$ and the absolute air humidity being $4.5-7.8 \mathrm{~kg}^{-3} \cdot \mathrm{m}^{-3}$. The ammonia concentration was $2.62-8.92 \mathrm{~kg}^{-6} \cdot \mathrm{m}^{-3}$, with the maximum allowable value in Russia being $20 \mathrm{~kg}^{-6} \cdot \mathrm{m}^{-3}$. This verified the sufficient air exchange in the barn, providing the necessary conditions for animals. With a decrease in temperature and an increase in humidity in the barn, the ammonia concentration dropped owing to the specific ammonia properties. As the study results, the regression models of ammonia concentration were created with $95 \%$ confidence level, depending on the air temperature in the barn.
\end{abstract}

Keywords: cow barn, inside climate, ammonia.

\section{Introduction}

Ammonia $\left(\mathrm{NH}_{3}\right)$ is significantly lighter than air and has high water solubility. In terms of the health effect, ammonia belongs to choking and neurotropic agents; under certain concentrations, it can cause the pulmonary edema and severe damage to the nervous system of the workers and animals. This establishes the need to monitor the ammonia content in the cow barn air.

In livestock houses, ammonia releases under decomposition of urine, manure and bedding. It chiefly accumulates in the rooms with inadequate ventilation and soiled floors, in bedding-free animal housing systems or when the bedding is not replaced regularly. In old and cold rooms, a lot of ammonia accumulates on the surface of the equipment and in wet bedding, as it is better dissolved in a cold humid environment.

The ammonia concentration in a cow barn depends on the animal productivity and lactation period, since the release of excrement depends on the diet associated with the lactation curve. Accordingly, the higher is the productivity, the greater is the yield of manure and ammonia emission in the barn [1].

Manure removal techniques and applied machines and equipment also have a significant effect on the ammonia content in the barn air [2;3].

Ammonia concentration monitoring is especially required in winter, when additional insulating measures are taken in the cow barns due to the negative outdoor temperatures and when the air exchange with the external environment is sharply reduced. In Russia, the maximum allowable $\mathrm{NH}_{3}$ content in the cow barn is $20 \mathrm{~kg}^{-6} \cdot \mathrm{m}^{-3}$ [4]. It is important not to exceed the standard values, as the surplus of ammonia concentration by $1 \mathrm{~kg}^{-6} \cdot \mathrm{m}^{-3}$ and the barn air moisture by $2 \%$ result in $1.7 \%$ lower milk productivity and $3.7 \%$ higher costs per unit of production [5].

\section{Materials and methods}

The study was conducted in February 2017 and February 2018 in the western part of Leningrad Region (the Russian Federation) in the cow barn, $72 \mathrm{~m}$ long and $21 \mathrm{~m}$ wide, for 200 lactating cows with the tied housing. Manure was removed from the barn twice a day and loaded into a vehicle for 
subsequent utilisation. In the study period, the natural ventilation was in place through the insulated roof ridge and via air infiltration through the openings in the structures. The barn was a part of the cattle-rearing complex consisting of several buildings, which were linked by a gallery on the northern side [6].

Air temperature, relative humidity and ammonia concentration were measured inside the barn in daytime according to the pattern shown in Fig.1. The data-recording interval in one point was 10 seconds during 10 minutes. For the study purpose, the room was divided into three zones A, B, C over the length. In each zone there were three points, where the above parameters were measured at a height of $1.4 \mathrm{~m}$ above the floor. External weather conditions were determined by the data from the state weather station located at a distance of $26 \mathrm{~km}$ from the cow barn.

An electronic device was used for measurements (Fig. 2), consisting of an electronic sensor with the current output of 4-20 mA and measuring the ammonia concentration in the range from 0 to $64 \mathrm{~kg}^{-6} \cdot \mathrm{m}^{-3}$, the temperature in the range from $-40{ }^{\circ} \mathrm{C}$ to $+100{ }^{\circ} \mathrm{C}$ and relative humidity - from 0 to $98 \%$. MSD-200 archiver with the 32 GB memory card allowed to archive the information obtained over a substantial period of time and to transfer it to the computer for analysis and Excel and Mathcad report generation [7]. Relative measurement error of ammonia concentration was $25 \%$; that of relative humidity did not exceed $\pm 3.0 \%$, and that of air temperature did not exceed $\pm 1.0{ }^{\circ} \mathrm{C}$.

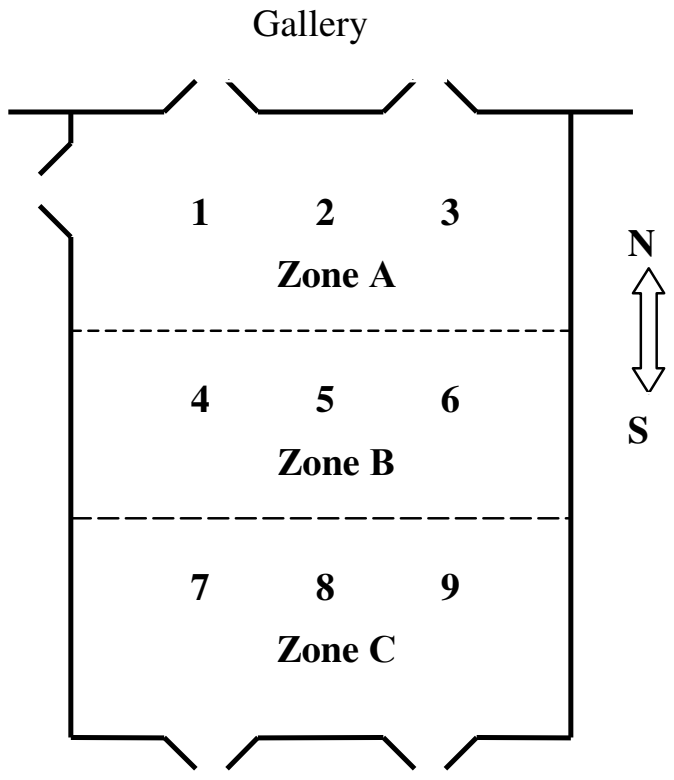

Fig.1. Measurement pattern of ammonia concentration and other air parameters

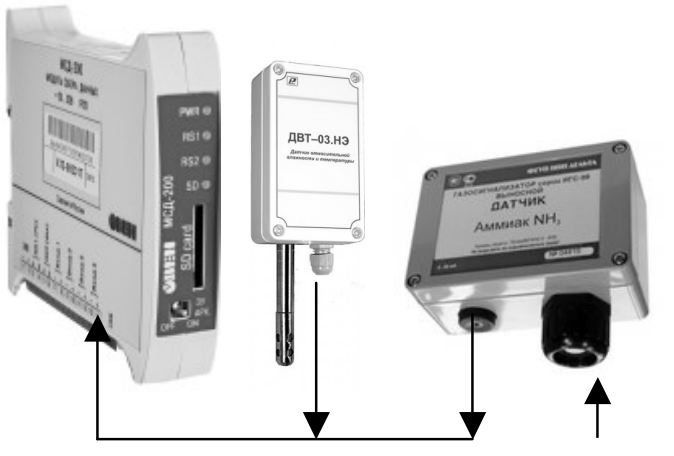

Data

Ammonia
Fig. 2. Measuring device of ammonia concentration and other air parameters

\section{Results and discussion}

Resulting from the previous studies [8], the distribution of temperature, moisture, and gas components of the barn air was found uneven and dependent on external factors, design features of the building, and cow housing and tending practice. Moreover, the major unevenness was observed along the length of the building, which is usually several times its width. In this regard, three zones were distinguished in the study (Fig. 1).

Zone A was in the northern part of the barn, adjacent to the gallery. Owing to the large gates, which occasionally opened even in the cold season, it had a significant air exchange with the environment. Zone $\mathrm{B}$ in the middle part of the barn had a limited air exchange through the roof ridge and window openings. Zone $\mathrm{C}$ was in the southern part of the barn. Like zone $\mathrm{A}$, it had large gates, which contributed to the air exchange with the environment. Zone A had measurement points 1, 2 and 3; zone $\mathrm{B}$ - measurement points 4, 5 and 6; zone $\mathrm{C}$ - measurement points 7,8 , and 9 . 
Generally, the air temperature and humidity have a major effect on ammonia concentration. Ammonia is lighter than air and has high water solubility - the lower is the water temperature, the higher is $\mathrm{NH}_{3}$ solubility [9].

The temperature and humidity inside the livestock house depended on the external weather conditions. Fig. 3 and Fig. 4 show the average temperature and average absolute humidity of the outside and inside air over the three observation days (6 and 8 February 2017 and 8 February 2018) under the relative air humidity of 72-84\%. It is important to note that the wind on those days was of different directions with the speed from 1 to $3 \mathrm{~m} \cdot \mathrm{s}^{-1}$. Variation of outdoor air temperature and relative humidity did not have a significant effect on the average values of these indicators inside the barn, but it did affect these parameters in particular zones of the barn.

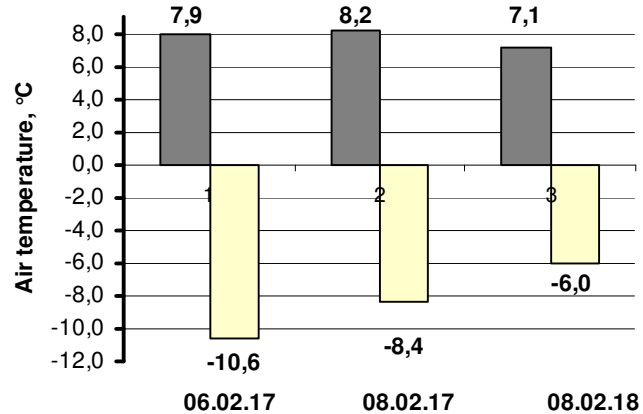

Fig.3. Air temperature

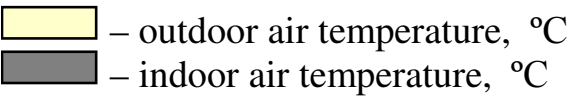

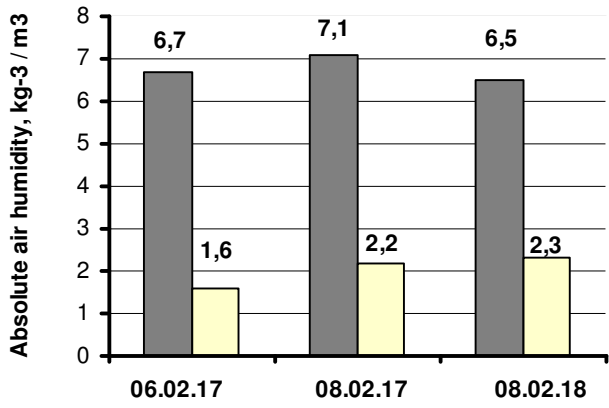

Fig.4. Absolute air humidity

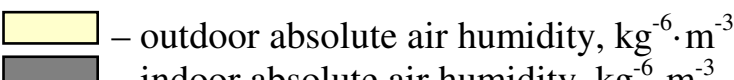

- indoor absolute air humidity, $\mathrm{kg}^{-6} \cdot \mathrm{m}^{-3}$

In addition, some other organizational and technological factors might be of importance, since one year passed between the measurements. Fig. 5 and Fig. 6 show the distribution of ammonia concentration across the barn. The graphs clearly demonstrate the uneven character of this distribution in the above zones. In zone A (points 1-3) the ammonia concentration was within 4-6 $9 \mathrm{~kg}^{-6} \cdot \mathrm{m}^{-3}$; in zone B (points 4-6) it was higher and might be up to $9 \mathrm{~kg}^{-6} \cdot \mathrm{m}^{-3}$; and in zone $\mathrm{C}$ the concentration decreased to 3-7 $9 \mathrm{~kg}^{-6} \cdot \mathrm{m}^{-3}$ and depended on the weather conditions and inside air parameters. The difference in the values between the graphs 1-2 and 3 (Fig. 5) is explained by the fact that in February 2018, a strong south-south-east wind was blowing on the side of zone $C$ (points 6-9), thereby creating an active barn air exchange with the outdoor environment.

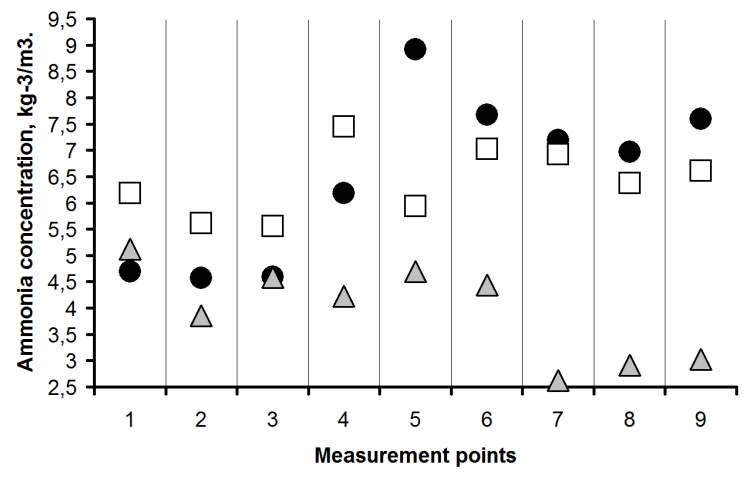

Fig. 5. Ammonia concentration in particular points in barn:

- - values registered on 06.02.2017

$\square$ - values registered on 08.02.2017

$\triangle_{-}$values registered on 08.02 .2018

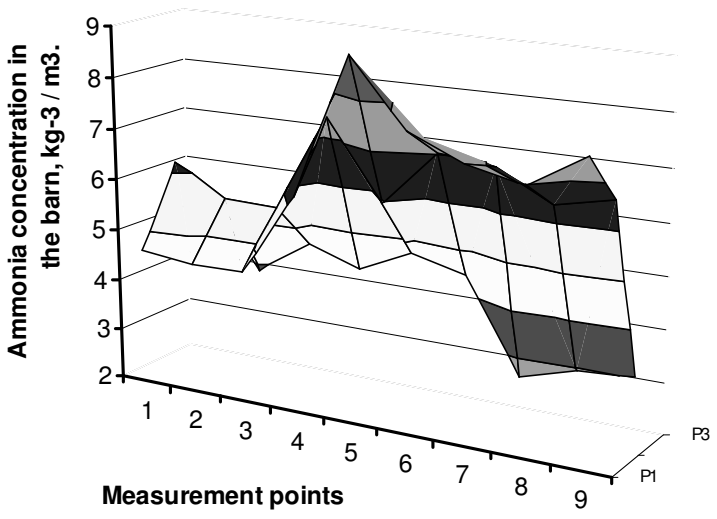

Fig. 6. Ammonia distribution in barn 
The dependence of the barn ammonia concentration on the air temperature and humidity is confirmed by the results of the studies presented in Fig.7 and 8. Graphs 1, 2 and 3 clearly show the relationship between the air temperature and absolute humidity with the ammonia concentration (Fig. 5 ) in the barn. With increasing the temperature and absolute humidity, the ammonia concentration also increases. Variation of these parameters across the barn zones is indicative.

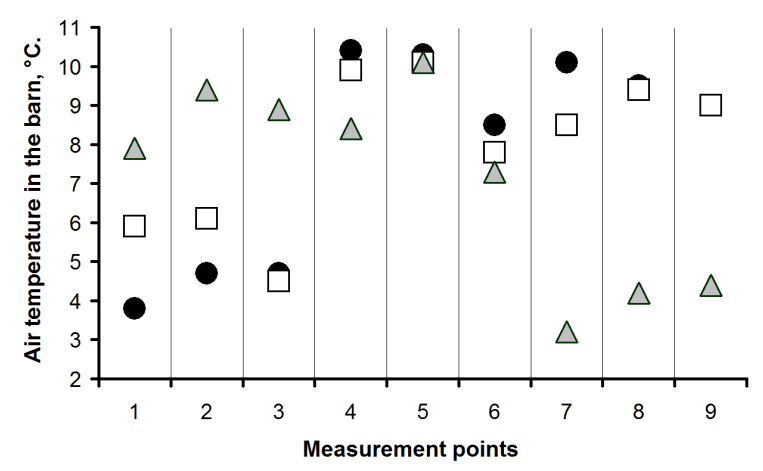

Fig. 7. Air temperature in particular points in barn

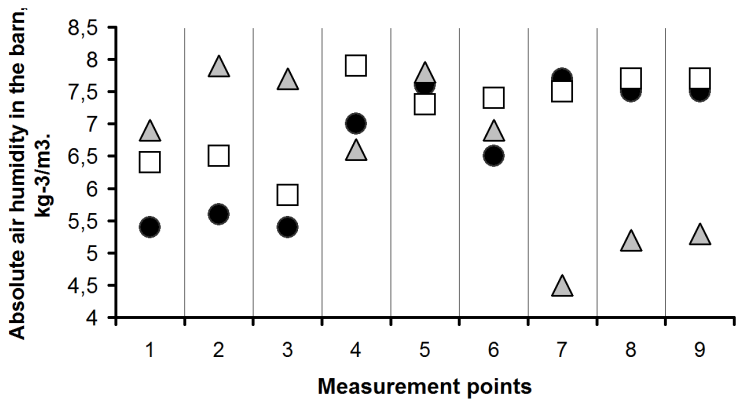

Fig. 8. Absolute air humidity in particular points in barn

Considering the temperature in the barn as the main factor, the regression analysis of the measurement results was performed and regression equations of ammonia concentration dependence on the temperature in the cow barn were obtained.

Regression equation (1) describes the temperature dependence of ammonia concentration for the study period on 6 and 8 February 2017 and 8 February 2018. Determination coefficient R2 $=0.304$ indicates a weak effect of temperature on ammonia concentration and a significant influence of several unaccounted factors over a long time period. In this case, more relevant are the changes in animal housing and tending practice and separate technological processes, alteration of constructive elements of the cow barn, as well as the need for the process discipline by the personnel, replacement of the animal stock and shift to other diets, differences in external climatic conditions (increase or decrease in annual temperatures, rainfall, etc.) and other factors, which cannot be described by mathematics.

$$
A=0.0035 T^{4}-0.0957 T^{3}+0.8615 T^{2}-2.484 T+5.386,
$$

where $A$-ammonia concentration, $\mathrm{kg}^{-6} \cdot \mathrm{m}^{-3}$;

$T$ - air temperature in the barn, ${ }^{\circ} \mathrm{C}$.

Regression equation (2) describes the temperature dependence of ammonia concentrations for the study period of 6 and 8 February 2017. In this case, the time between the measurements is only two days, and most factors are constant and fixed and, accordingly, the variation of the air temperature has a major effect. This is confirmed by the determination coefficient, the value of which $\mathrm{R} 2=0.807$ indicates a close relationship between the variables.

$$
A=0.0073 T^{4}-0.2425 T^{3}+2.7745 T^{2}-12.52 T+24.101 \text {. (2) }
$$

Each regression equation (3-5) describes the dependence of ammonia concentration on the temperature on particular day: equation (3) - 6 February 2017, equation (4) - 8 February 2017, and equation (5) -8 February 2018. In this case, the data were recorded within few hours and the values of unaccounted factors have minor variation. This is evidenced by the high values of the determination coefficients $R 2=0.974,0.872$, and 0.928 , accordingly, confirming the close relationship between the air temperature and ammonia concentration in the barn.

$$
\begin{gathered}
A=0.0081 T^{4}-0.2908 T^{3}+3.5178 T^{2}-16.727 T+31.711, \\
A=0.0204 T^{4}-0.6433 T^{3}+7.2768 T^{2}-34.659 T+64.45, \\
A=-0.0035 T^{4}+0.0484 T^{3}-0.1371 T^{2}+0.0415 T+2.672 .
\end{gathered}
$$

The study results have shown that under the short-term forecasting in the time interval up to $24 \mathrm{~h}$ the ammonia concentration in the barn may be calculated with a probability of $80-90 \%$ by the mathematical models based on one factor, the air temperature in the barn, taking into account the 
weather forecast for the same period [10]. Models for calculating the ammonia concentrations over a longer period should take into account a number of factors. In this case, the longer is the time interval, the more factors are to be considered.

\section{Conclusions}

1. Ammonia is significantly lighter than air and has high water solubility. In terms of the health effect, ammonia belongs to choking and neurotropic agents; under certain concentrations, it can cause the pulmonary edema and severe damage to the nervous system of the workers and animals. This establishes the need to monitor the ammonia content in the cow barn air, especially in winter, when additional insulating measures are taken in the cow barns due to the negative outdoor temperatures and when the air exchange with the external environment is sharply reduced. In Russia the maximum allowable $\mathrm{NH}_{3}$ concentration is set at $20 \mathrm{~kg}^{-6} \cdot \mathrm{m}^{-3}$.

2. The study was conducted in February 2017 and February 2018 in a cow barn with the tied housing system and natural ventilation through the insulated roof ridge. It demonstrated the pronounced zonal distribution of ammonia concentration in the barn ranging from 2.5 to $9 \mathrm{~kg}^{-6} \cdot \mathrm{m}^{-3}$ and depending on the indoor air temperature and humidity. This complies with the established standards.

3. The study results have shown that under the short-term forecasting in the time interval up to $24 \mathrm{~h}$ the ammonia concentration in the barn may be calculated with a probability of $80-90 \%$ by the mathematical models based on one factor, the air temperature in the barn, taking into account the weather forecast for the same period.

4. Models for calculating the ammonia concentrations over a longer period should take into account a number of factors. In this case, the longer is the time interval, the more factors are to be considered.

\section{References}

[1] Текучев И.К., Черновол Ю.Н. Зависимости объема выделяемых коровой экскрементов от ее продуктивности (Dependencies of cow excrement volume on cow productivity). Bulletin of VNIIMzH: Вестник ВНИИМЖ No. 1(25). 2017. pp. 40-43. (In Russian)

[2] Kai P., Adamsen Anders P. S., Jensen Morten L., Kasper Pernille og Feilberg Anders. Ammonia emission from Danish cubicle barns for dairy cows-effect of floor type and manure scraping. DCA Report No. 110. Aarhus. 2017: 64.

[3] Priekulis J., Melece L. Ammonia emission reduction possibilities from dairy farms. Proceedings of $17^{\text {th }}$ International Scientific Conference "Engineering for rural development" May 23-25, 2018. Jelgava, Latvia, pp. 52-56.

[4] РД-АПК 1.10.01.01-18. Методические рекомендации по технологическому проектированию ферм и комплексов крупного рогатого скота (Management Directive for Agro-Industrial Complex. Recommendations on technological designing of cattle farms and complexes). Moscow: Rosinformagrotech: Москва: Росинформагротех. 2018. 166 p. (In Russian)

[5] Юрков В.М. Микроклимат животноводческих ферм и комплексов. (Inside climate in livestock farms and complexes). Moscow Rosselkhozizdat: М. Россельхозиздат, 1985. 223 p. (In Russian)

[6] Vtoryi V., Vtoryi S., Ylyin R. Investigations of temperature and humidity conditions in barn in winter. Proceedings of $17^{\text {th }}$ International Scientific Conference "Engineering for rural development" May 23-25, 2018, Jelgava, Latvia. pp. 265-269.

[7] Валге А.М. Использование систем Excel и Mathcad при проведении исследований по механизации сельскохозяйственного производства (Application of Excel and Mathcad in investigations associated with mechanisation of agricultural production). Saint Petersburg: SZNIIMESH Rosselkhzacademii: СПб: ГНУ СЗНИИМЭСХ Россельхозакадемии. 2013. 200 р. (In Russian)

[8] Ильин Р.М., Вторый C.В. Обоснование параметров системы мониторинга микроклимата в животноводческих помещениях (Substantiation of parameters of climate monitoring system in livestock houses). Technologies, machines and equipment for mechanised crop and livestock 
production: Технологии и технические средства механизированного производства продукции растениеводства и животноводства. 2017. No. 92. pp. 212-217. (In Russian)

[9] Herbut P., Angrecka S. Ammonia concentrations in a free-stall dairy barn Ann. Anim. Sci., Vol. 14, No. 1 (2014): 153-166. DOI: 10.2478/aoas-2013-0065.

[10]Вторый В.Ф., Вторый С.В., Ильин Р.М. Модель температурно-влажностного режима коровника в зависимости от параметров внешней среды (Model of in-barn temperature and humidity depending on outside environment parameters). Technologies, machines and equipment for mechanised crop and livestock production: Технологии и технические средства механизированного производства продукции растениеводства и животноводства. 2018. No. 3 (96). pp. 203-209. (In Russian) 